\title{
Drivers and Barriers to Adoption of Multivendor ATM Technology in India: Synthesis of Three Empirical Studies
}

\author{
Jyotiranjan Hota \\ KIIT School of Management, Bhuvaneswar (Odisha) \\ Saboohi Nasim \\ Aligarh Muslim University, Aligarh (UP) \\ Sasmita Mishra \\ KIIT School of Management, Bhuvaneswar (Odisha)
}

\begin{abstract}
As an incremental change to single vendor ATM Technology, multivendor (MVS) ATM technology has already penetrated into Indian Market. However, its growth in Indian market may depend on several factors. Understanding the drivers and barriers from the point of view of all the stakeholders of this technology can provide a preliminary understanding about its growth in India. This paper attempts to compile the empirical findings from three studies on three stakeholders and provides a synthesized finding on the possible drivers and barriers of this technology implementation in India.
\end{abstract}

Key Words: Single Vendor ATM Technology, Multivendor ATM Technology, Technology Adoption and ATM Software

\section{INTRODUCTION}

There has been a remarkable shift in the banking policies and banking technology in the recent decade. Till date, ATMs have been the most favorable technology in the developing countries (Sathye \& Sathye, 2017). The safety and convenience attached to this technology, had contributed to its popularity. To enhance the convenience for bankers and customers, this technology has been upgraded to a new technology called Multivendor (MVS) ATM Technology. This new technology has many more added features aimed at benefiting the customers and bankers. For example, this technology with personalized features and better interaction experience has been projected to enhance customer services.

On the other hand, as banks can buy software and hardware from different vendors, vendors/suppliers would face competitive pressure to maintain quality. Consequently, banks can make independent decisions in opting for hardware suppliers. This technology will also help in reducing the cost of ownership of ATMs for the banks and reduce infrastructure management issues.

The specific technological advantages of this technology are: it facilitates open operating systems, central ATM monitoring with TCP/IP based network. However, single vendor ATM technology is usually assisted by closed operating systems and X.25 and SNA based networks. Monitoring ATMs, down-

Journal of Technology Management for Growing Economies Vol. 9, No. 1 April, 2018 pp. 89-101

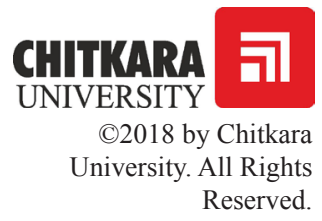


Hota, J.

Nasim, S.

Mishra, S. loading patches and resolving security concerns are difficult due to lack of central monitoring. Multivendor ATMs can resolve these issues remotely. Generic interface such as XFS standard ensures that single remote monitoring tool can manage ATM networks rather than vendor specific tools.

This technology has been well accepted in developed countries. However, the exclusive socio-politico and technological context of India may have unique issues in the path of implementation of this technology. The issues might be there from supplier, banks as well as customer point of view. Every technology faces certain drivers and barriers in macro and micro level. Proper understanding of such barriers and drivers helps the implementing agencies to implement the technology smoothly.

\section{REVIEW OF LITERATURE}

A significant part of technology adoption literature highlights the drivers and barriers in the adoption of technology by the users. However, certain studies are also there that talks about the facilitators and inhibitors in the adoption of technology from the point of view of other stakeholders. This section narrates such studies with respect to different technologies along with ATM and Multivendor ATM Technology.

Luken \& Rompaey (2008) had conducted a survey on plant managers and key informants to study the drivers and barriers of environmentally sound technology adoption. They found environmental regulation, market pressure and community pressure as important influencing factors. Similarly del Río González (2005) had conducted a study on clean technology adoption and reported three drivers/barriers such as: internal and external factors of the firm; conditions of the potential adopters; and characteristics of environmental technology. Iacovou et al. (1995) had identified three major factor influencing EDI adoption: organisational readiness, external forces and perceived benefits of the technology. Based on literature, Henriksen (2002) summarizes a broad range of drivers and barriers for different technologies such as e-commerce, EDI, IS, and IT. Some of the factors identified by him are: environmental factors, policy factors, organizational factors, nature of technology, perceived benefit, external pressure etc.

Barriers to any technology adoption are most of the time considered as the issues that hinder access to technology. McCreadie and Rice (1999) have identified six types of issues such as: i) physical (whether a medium is physically accessible or not); 2) cognitive accessibility (has to do with understanding how systems work); 3) Affective (attitudes and motivation with regard to use of systems; 4) Economic accessibility is related to cost and benefit; 5) Social accessibility refers to social norms; 6) Political accessibility refers to power and knowledge gap.

Journal of Technology Management for Growing Economies, Volume 9, Number 1, April 2018 
From the individual user's point of view, Dwivedi, Lal and Willaims (2009) had found several factors such as utilitarian outcome, social influence, self-efficacy and facilitating condition resources as drivers and age as a barrier in the adoption of broadband technology. Few studies reveal that novelty and convenience create curiosity among people and in turn, changes the attitude of people towards it (Wells, Campbell, Valacich and Featherman, 2010; Cox and Locander, 1987; Lee, 2013). On the other hand, people are less likely to adopt a technology which is complex and requires more cognitive effort (Dickerson and Gentry, 1983).

To understand the drivers and barriers to technology adoption by end users, technology adoption models derived from TAM (Davis, 1989) have been useful. Most of the models are cognitive maps to understand the adoption process of any technology (Cavas, Karaoglan and Kisla, 2009; Karjaluoto, Mattila and Pento, 2002). The common constructs identified in those studies are awareness about the technology, perceived usefulness, perceived ease of use, self-efficacy, social norms, attitude towards technology, intention to use and different demographic factors such as age, gender, income etc. (Asing-Cashman., Gurung, Limbu and Rutledge, 2014).

Studies specific to banking services identified several factors that influence attitude towards the technology and its usage such as customer demographics, past experience of handling technology, personal experience in banking, reference group influence, a person's behavior towards different banking technologies, individual acceptance of new technology, computer competency, personal control and cultural perception of technology (Albirini, 2006; Laforet and Li, 2005; Averill, 1973).

\section{METHODOLOGY}

This study attempts a synthesis of learning of drivers and barriers to Multivendor ATM adoption in India from all stakeholders' perspectives. Authors try to refer secondary literature and their own empirical findings to arrive at some concluding remarks. In case of banks and suppliers, identified drivers and barriers are further validated through expert survey. Subsequently, a qualitative modeling i.e. TISM (Total Interpretative Structural Modeling) is applied to further find out the interrelationship among drivers and barriers (Sushil, 2005a; Sushil, 2005b; Sushil, 2012). Customer Model was an empirical testing on a proposed model through the use of AMOS. However, the drivers and barriers discussed in this paper are a subset of the entire adoption model relating to customer.

\section{DESCRIPTION OF THE STUDY}

Three different studies were conducted to identify the drivers and barriers from the perspective of supplier, bankers and customers. The method adopted

Drivers and

Barriers to Adoption of Multivendor 
Hota, J.

Nasim, S.

Mishra, S. for suppliers and bankers study was TISM and the customer study was based on Davis's TAM model.

Suppliers'study

A comprehensive literature review on drivers and barriers to adopt multivendor ATM technology by suppliers was undertaken by researchers(Johnson, 2013; Atmmarketplace, 2014; Cluckey,2013;RBR, 2010; Macmillan, 2008; Hota, 2012; Levelfour, 2008; Celent, 2007; Retail banking research, 2007; Cluckey, 2016; Korala, 2013; De Angeli et al., 2004; Kulkarni, 2011) to identify an exhaustive list of drivers and barriers. Then domain experts (see figure.1 for the profile of the experts) were consulted to filter out the drivers and barriers specific to the Indian context.

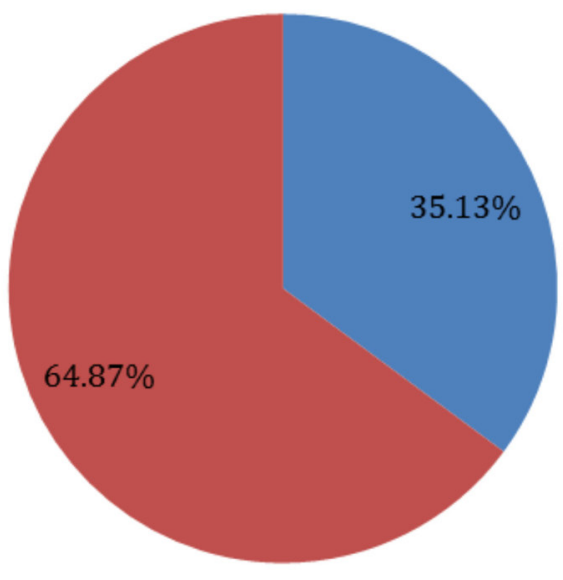

Managers of ATM suppliers/Vendors

- Technical and technofunctional experts of Suppliers/Vendors

Figure 1: Profile of Suppliers as Experts

Source: Hota, J(2017).Adoption of Multivendor ATM Technology in India(Unpublished doctoral dissertation). Aligarh Muslim University, Aligarh, India

A brief explanation of these drivers and their references is summarized in Table 1. Following the TISM process, significant drivers and barriers were validated by domain experts. The drivers included: New Hardware Technology, Multivendor Software Environment, Remote ATM Monitoring, Open Network Architecture, Generic Interface and Services. On the other hand, the specific barriers include: XFS fulfillment and EMV compliance issue, Software Configuration and Change Management Issues, Security Risk, Operating System Migration, Disintegrated Monitoring, Cultural Issues and Changing Government Regulations (see figure 3 \& figure 4 for the relative importance of drivers and barriers as rated by the domain experts). 


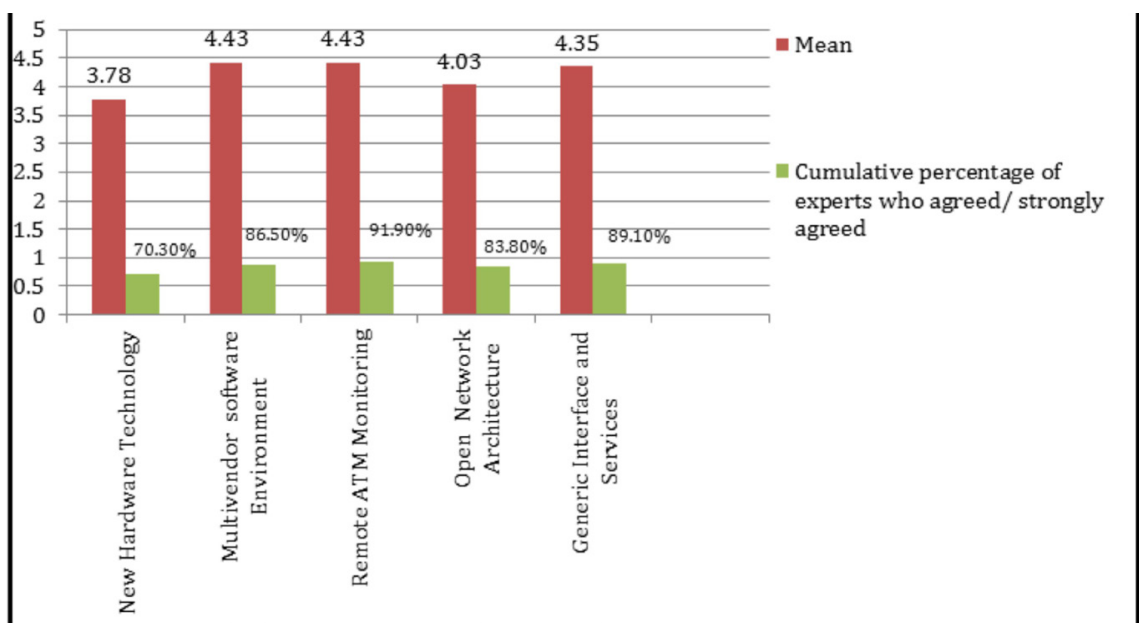

Drivers and

Barriers to Adoption of

Multivendor

Figure 2: Endorsement of Supplier Drivers by Experts

Source: Hota, J.(2017).Adoption of Multivendor ATM Technology in India(Unpublished doctoral Dissertation). Aligarh Muslim University, Aligarh, India

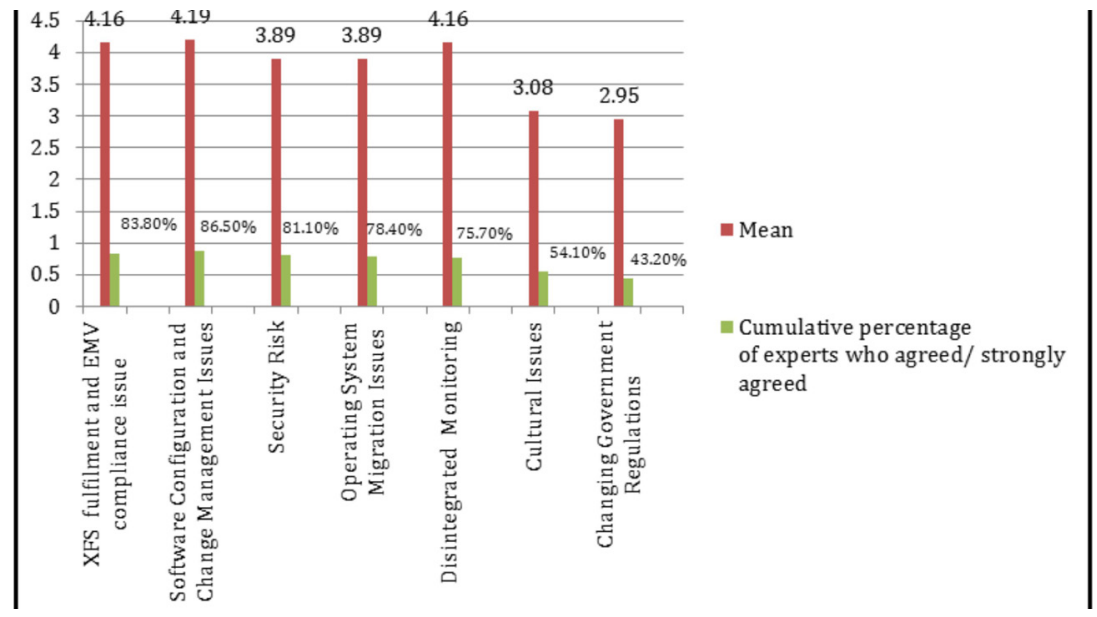

Figure 4: Endorsement of Supplier Barriers by Experts

Source: Hota, J. (2017).Adoption of Multivendor ATM Technology in India (Unpublished doctoral dissertation). Aligarh Muslim University, Aligarh, India

\section{Bankers'study}

Similar process was adopted to identify drivers and barriers for bankers from literature (Race, 2010; Wollenhaupt, 2010; Slawsky, 2013; RBR, 2010; Greengard, 2009; Yili, 2011 ; Kal, 2011; Ghosh, 2013; ATM marketplace, 2014; Jetley, 2014). Ten drivers and five barriers were finally identified and shortlisted by the domain experts (see figure. 2 for the profile of the experts)for further analysis. 
Hota, J.

Nasim, S.

Mishra, S.

94

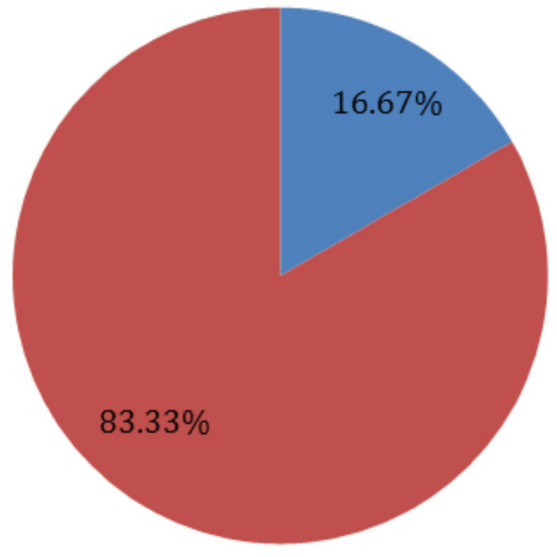

- Academicians/Researche rs in Banking Area

Experts working in

Banks and related technology projects in industry

Figure 2: Profile of Expert in Banks

Source: Empirical study by the Authors (Hota and Nasim, 2015)

The select drivers of MVS ATM Technology for bankers are Perceived ease of use, New Technology, Cost Control, Vendor Independence, Network unification, Increased Security, Analytics Capabilities, Real time ATM Monitoring, Standardization of management and maintenance, and Simplified ATM Purchase. The select barriers of multivendor ATM Technology for bankers are Regulatory Issues, Complexity in working with ATM suppliers, Lack of overall control, Telecom Infrastructures Issue and Power Availability Issue (see figure $5 \&$ figure 6) for the relative importance of drivers and barriers as rated by the domain experts).

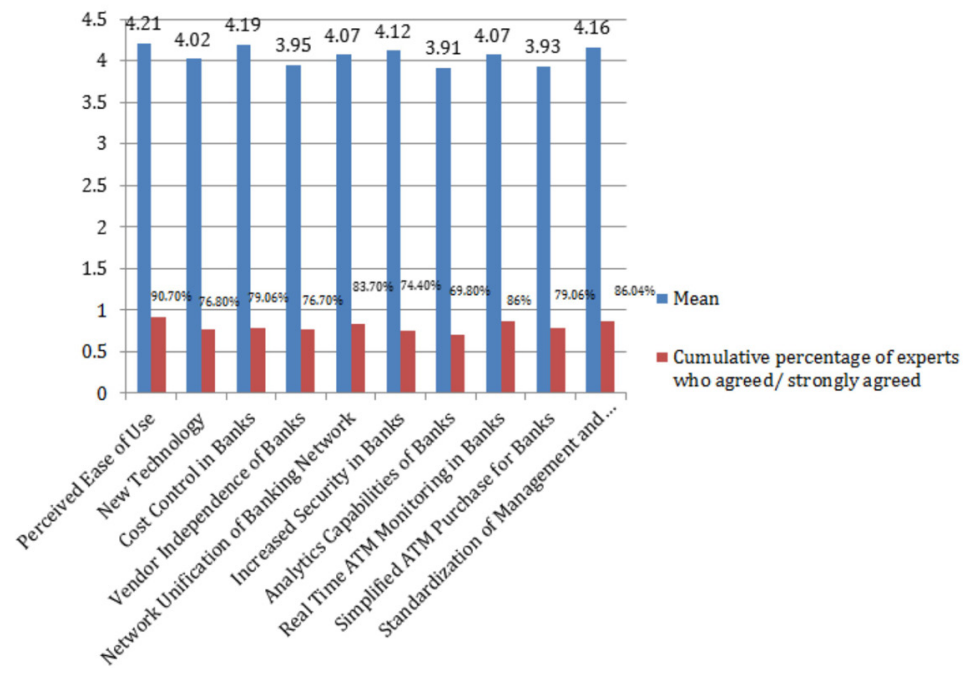

Figure 5: Endorsement of Bank Drivers by Experts Source: Empirical study by the Authors (Hota and Nasim, 2015) 


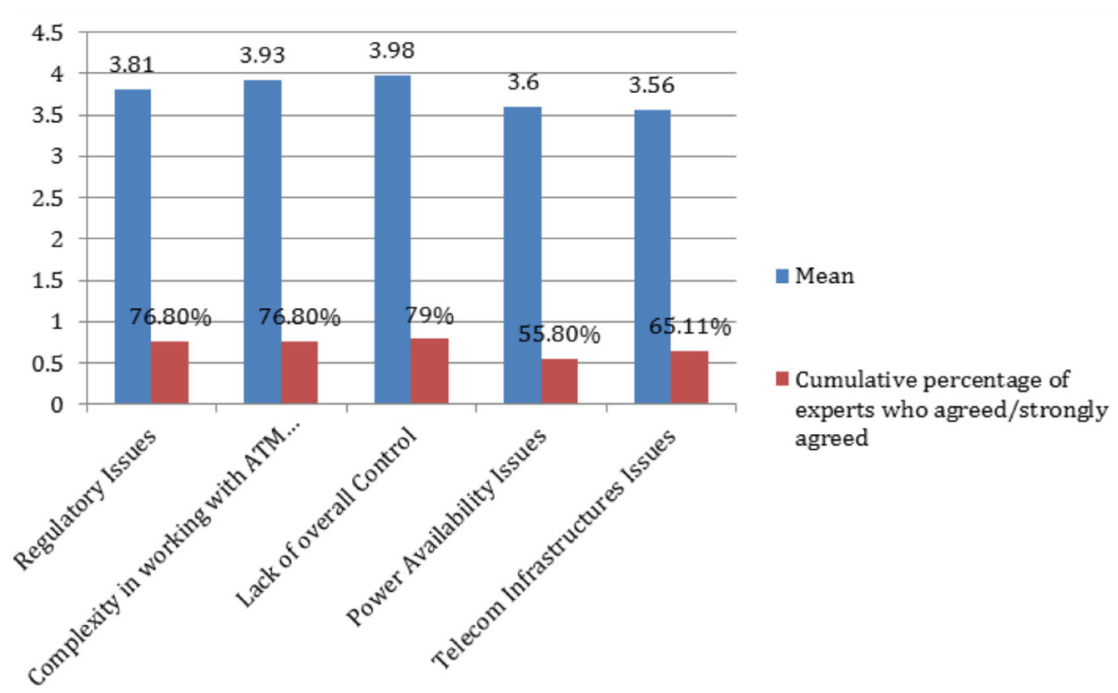

Drivers and

Barriers to Adoption of

Multivendor

Figure 6: Endorsement of Bank Barriers by Experts

Source: Empirical Study By The Authors (Hota \& Nasim, 2015)

\section{Customers'study}

Customer study was based on Technology Acceptance Model. Hence, referring to relevant literature (Davis, 1989; Kumar, Malathy and Ganesh, 2011; Joshua,2009; De Anjeli et al., 2004 ) on ATM technology, online/mobile banking and other technology, several factors were identified and a adoption process model was developed and tested (Hota \& Mishra, 2018). The factors identified in this study were perceived ease of use, perceived usefulness, perceived complexity, perceived risk, awareness, attitude, intention, predictability, controllability, outcome desirability control and perception of personalized features(Curran and Meuter,2005; Davis,1989; Davis et al.,1989; Venkatesh and Davis, 2000; Moutinho and Meidan,1989;Lee and Allaway,2002; Hill, Smith, and Mann,1987; Averill,1973; Tetrick and LaRocco,1987; Mishra and Suar,2007; Marshall and Heslop,2007). It was found out that awareness and outcome desirability had strong correlation with usage behavior. Unlike Technology Acceptance Model, perceived ease of use, attitude and intentions were found to be insignificant factors (Table 1).

Table 1. Correlation between predictor variables and usage behavior

\begin{tabular}{|l|c|}
\hline & Usage Behavior \\
\hline Awareness & $.223^{* *}$ \\
\hline Perceived usefulness & .072 \\
\hline
\end{tabular}

Journal of Technology Management for Growing Economies, Volume 9, Number 1, April 2018 
Hota, J.

Nasim, S.

Mishra, S.

\begin{tabular}{|l|c|}
\hline Perceived ease of use & $-.132^{* *}$ \\
\hline Perceived Complexity & $.197^{* *}$ \\
\hline Perceived Risk & .053 \\
\hline Personalized features & $.166^{* *}$ \\
\hline Predictability & $-.110^{*}$ \\
\hline Controllability & $.163^{* *}$ \\
\hline Outcome desirability & $.360^{* *}$ \\
\hline Intention & .066 \\
\hline Attitude & .086 \\
\hline
\end{tabular}

Note: $\mathrm{N}=372 ; * \mathrm{p}<.01 ; * * \mathrm{P}<.001$

Source: empirical study by authors (Hota \& Mishra, 2018, forthcoming)

\section{SYNTHESIS OF THE FINDINGS}

A synthesis of the key findings of the research conducted by the authors across different phases and methodologies employed are summarized. The synthesis also includes findings from secondary literature; 'drivers of adoption' and 'barriers to adoption' has been compared and summarized for all the three stakeholders of the study. Table 2 provides a synthesis of key findings from Bank, Supplier and Customer study, thus, presenting a holistic understanding of the adoption of multivendor ATM Technology in India.

Table 2. Synthesis of Key Findings from Bank, Supplier and Customer Study

\begin{tabular}{|c|c|c|c|}
\hline $\begin{array}{l}\text { Stakeholders } \\
\text { Dimensions }\end{array}$ & Bank & Supplier & Customer \\
\hline \multirow{3}{*}{$\begin{array}{l}\text { Drivers for } \\
\text { Adoption }\end{array}$} & $\begin{array}{l}\text { There are a greater } \\
\text { consensus and a stronger } \\
\text { endorsement of the drivers } \\
\text { by the experts }\end{array}$ & $\begin{array}{l}\text { There are a greater } \\
\text { consensus and a stron- } \\
\text { ger endorsement of the } \\
\text { drivers by the experts. }\end{array}$ & \multirow{3}{*}{$\begin{array}{l}\text { Personalized } \\
\text { features, Aware- } \\
\text { ness and certain } \\
\text { personal control } \\
\text { variables are } \\
\text { primary drivers } \\
\text { to adoption } \\
\text { of MVS ATM } \\
\text { Technology. }\end{array}$} \\
\hline & $\begin{array}{l}\text { All ten drivers identified } \\
\text { from literature are accept- } \\
\text { ed by expert validation }\end{array}$ & $\begin{array}{l}\text { All five drivers iden- } \\
\text { tified from literature } \\
\text { are accepted by expert } \\
\text { validation }\end{array}$ & \\
\hline & $\begin{array}{l}\text { 'New Technology' is found } \\
\text { to be the primary driver. }\end{array}$ & $\begin{array}{l}\text { 'Open Network Archi- } \\
\text { tecture' is found to be } \\
\text { the primary driver }\end{array}$ & \\
\hline
\end{tabular}

Journal of Technology Management for Growing Economies, Volume 9, Number 1, April 2018 


\begin{tabular}{|l|l|l|l|}
\hline \multirow{3}{*}{$\begin{array}{l}\text { Barriers to } \\
\text { Adoption }\end{array}$} & $\begin{array}{l}\text { All five barriers identified } \\
\text { from literature are accept- } \\
\text { ed by expert validation }\end{array}$ & $\begin{array}{l}\text { Out of seven barriers, } \\
\text { five barriers are accept- } \\
\text { ed by expert validation } \\
\text { and two barriers were } \\
\text { rejected }\end{array}$ & $\begin{array}{l}\text { Lack of } \\
\text { awareness and } \\
\text { lower perceived } \\
\text { control are the } \\
\text { major barriers to } \\
\text { adoption. }\end{array}$ \\
\cline { 2 - 3 } & $\begin{array}{l}\text { 'Telecom Infrastructure } \\
\text { Issue' is found to be the } \\
\text { primary barrier }\end{array}$ & $\begin{array}{l}\text { 'XFS Fulfillment and } \\
\text { EMV Compliance } \\
\text { Issue' was found to be } \\
\text { the primary barrier }\end{array}$ & $\begin{array}{l}\text { Drivers and } \\
\text { Adoption of } \\
\text { Multivendor }\end{array}$ \\
\hline
\end{tabular}

\section{CONCLUSION AND FUTURE RESEARCH DIRECTION}

Experts find lots of potential for multivendor ATM technology to be established in Indian market (ANI, 2017; Swaminathan, 2017; Bhakta and Nair, 2017).).This study corroborates such predictions by identifying the drivers and barriers. The construct 'New Technology' of MVS ATM services has emerged to be the most important driver for the banks which further drives real time monitoring, ease of use of ATM services, vendor independence and standardized management and maintenance for banks. Banks can also support analytics capabilities which provide products and services offerings as per the past ATM transactions of the customers. All of these perceived benefits are facilitating simplified ATM purchase and adoption of Multivendor ATM Technology banks. Issues of telecommunication infrastructure as the primary barrier for the banks in controlling the overall environment of multivendor ATMs. This further creates problems to connect telecom tower with power sources.

There are challenges raised to control overall multivendor ATM environment due to presence of multiple suppliers, which needs to be addressed. 'Open network architecture' has emerged to be the primary driver for the suppliers, which facilitates in avoiding the lock-in of banks with the suppliers and resolves inter-operability issues, thus, providing a generic interface and banking services to customers. Lack of compliance of extensible financial services and EMV (Euro, Master and Visa) emerged to be a major barrier for the suppliers as it creates problems for them while migrating from single to multivendor ATM environment. Due to lack of coordination among security events, there is possibility of security risks in the network. Lack of coordination is the result of separate follow up of 'ATM Applications' and 'ATM Monitoring'.

Personalized features, Awareness and certain personal control variables are primary drivers to adoption of Multivendor ATM Technology from the perspective of customers. Similarly, Lack of awareness and lower perceived control are the major barriers to adoption.

Journal of Technology Management for Growing Economies, Volume 9, Number 1, April 2018 
Hota, J.

Nasim, S.

Mishra, S.

Based on the insights gained from this research, some of the key suggestions for future research are discussed below: Looking at the barriers of Multivendor ATM identified here, an action research involving Govt. and other agencies involved in Multivendor ATM implementation can provide solutions to the issues pertaining to multivendor ATM adoption in India. This Multivendor ATM Technology adoption study can be applied to other developing countries. Banks in India are now competing among themselves to provide better services to the customers on a one-to-one basis. Banks are also going for cross selling and up selling opportunities to attract customers as per their personalized ATM transactions. There is an attempt by forward thinking banks to move from Multivendor ATM to multi-channel integration so as to understand the customers in totality. The study has a very strong relevance in academic literature. To provide insight into the further development of this technology and provide more and more services to the customers, lots of studies are required in this field.

\section{REFERENCES}

RBR (2016) Two million ATMs to run MVS application software by 2020. https://www. rbrlondon.com/about/ASW16_Press_Release_310516.pdf Accessed 20 Dec 2016

Hota, J. and Nasim, S (2015) "Drivers and Barriers in Adopting MVS ATM Technology for Banks in India", Available at SSRN 2712659.

Lozano, M. F (1987) "The Diffusion and Adoption of a Technical Innovation: The Automated Teller Machine, Ph.D. Dissertation, Phoenix, The University of Arizona.

Joshua, A.J (2009) "Adoption of technology-enabled banking Self-services: Antecedents and Consequences (Doctoral dissertation, COCHIN UNIVERSITY OF SCIENCE AND TECHNOLOGY).

Kal.(2010) "The Future of ATM Software, Available at http://www.usfst.com/article/Thefuture-of-ATM- software/accessed on 20.12.2011.

McEwan, H (2011) "Recent Innovations in ATM Software available at http://ezinearticles. com/?Recent-Innovations-In-ATM-Software \&id=6464985 accessed on 01-12-2011.

Slawsky, R (2011) "Engaging the ATM Customer with Intelligent Personalization, available at http://www.atmmarketplace.com/whitepapers/2581/Engaging-the-ATM-Customer-withIntelligent- Personalization accessed on 16-12-2011.

Cavas, B., Cavas, P., Karaoglan, B., \& Kisla, T (2009) “A Study on Science Teachers’ Attitudes toward Information and Communications Technologies in Education", Online Submission, 8(2): 20-32.

Iacovou, C. L., Benbasat, I., \& Dexter, A. S.(1995) "Electronic data interchange and small organizations: Adoption and impact of technology", MIS quarterly, 465-485.

Henriksen, H. Z.(2002) "Performance, pressures, and politics: motivators for adoption of interorganizational information systems", Samfundslitteratur.

Hill, T., Smith,N.D. \& Mann, M. F. (1987) "Role of efficacy expectations in predicting the decision to use advanced technologies: The case of computers", Journal of applied psychology, 72(2), 307-313. https://dx.doi.org//10.1037/0021-9010.72.2.307.

Karjaluoto, H., Mattila, M., \& Pento, T (2002) "Factors underlying attitude formation towards online banking in Finland", International Journal of Bank Marketing, 20(6): 261-272.

Journal of Technology Management for Growing Economies, Volume 9, Number 1, April 2018 
https://doi.org/10.1108/02652320210446724.

Asing-Cashman, J. G., Gurung, B., Limbu, Y. B., \& Rutledge, D (2014) "Free and Open Source Tools (FOSTs): An Empirical Investigation of Pre-Service Teachers' Competencies, Attitudes, and Pedagogical Intentions", International Journal of Teaching and Learning in Higher Education, 26: 66-77.

Bhakta,P.,\& Nair,A.(2016) "Banks may soon provide personal loan through ATM machine availableathttps://economictimes.indiatimes.com/wealth/borrow/banks-may-soonprovide-personal-loan-through-atm-machine/articleshow/53851216.cmsfetchedon 23.07.2017.

Albirini, A. (2006) "Teachers' attitudes toward information and communication technologies: The case of Syrian EFL teachers.Computers \& Education, 47(4): 373-398.

Laforet, S., \& Li, X. (2005) "Consumers' Attitudes Towards Online and Mobile Banking in China", International Journal of Bank Barketing, 23(5): 362-380. https://dx.doi. org/10.1108/02652320510629250

Hota, J. (2013) "Growth of ATM Industry in India, Computer Society of India Communications, 36(11): 23-25.

Wells, J. D., Campbell, D. E., Valacich, J. S., \& Featherman, M. (2010) "The Effect of Perceived Novelty on the Adoption of Information Technology Innovations: A Risk/ Reward Perspective", Decision Sciences, 41(4): 813-843. https://doi.org/10.1111/j.15405915.2010.00292.x.

Curran, J. M., \& Meuter, M. L.(2005) "Self-service technology adoption: comparing three technologies", Journal of Services Marketing, 19(2), 103-113. https://doi. org/10.1108/08876040510591411.

Marshall, J. J., \& Heslop, L. A.(1988) "Technology Acceptance in Canadian Retail Banking: Study of Consumer Motivations and Use of ATMs", International Journal of Bank Marketing, 6(4), 31-41. https://doi.org/10.1108/eb010836.

Cox, D. S., \& Locander, W. B. (1987) "Product novelty: does it moderate the relationship between ad attitudes and brand attitudes?", Journal of Advertising, 16(3): 39-44. https:// doi.org/10.1080/00913367.1987.10673084.

Lee, M. K. (2013) "Designing Personalization in Technology-Based Services (Doctoral dissertation, Microsoft Research).

Kalyanaraman, S., \& Sundar, S. S. (2006) "The psychological appeal of personalized content in web portals: does customization affect attitudes and behavior?", Journal of Communication, 56(1): 110-132. https://doi.org/10.1111/j.1460-2466.2006.00006.x.

Dickerson, M. D., and Gentry, J. W. (1983) "Characteristics of adopters and non-adopters of home computers", Journal of Consumer Research, 10(2), 225-235.

Seligman, M. E. P. Helplessness. San Francisco, Calif.: Freeman, 1975.

Averill, J. R. (1973) 'Personal control over aversive stimuli and its relationship to stress. Psychological bulletin, 80(4): 286-303.

Triandis, H. C. (1979) "Values, attitudes, and interpersonal behavior. In Nebraska symposium on motivation", University of Nebraska Press.

Bandura, A. (1977) "Social Learning Theory, Prentice Hall: Englewood Cliffs, N.J.

Bandura, A. (1982) "Self-efficacy mechanism in human agency", American psychologist, 37(2): 122-147.

Mun, Y.Y., \& Hwang, Y. (2003) "Predicting the Use of Web-based Information Systems: Self-Efficacy, Enjoyment, Learning Goal Orientation, and The Technology Acceptance Model", International Journal of Human-computer Studies, 59(4): 431-449. https://doi. org/10.1016/S1071-5819(03)00114-9.
Drivers and

Barriers to Adoption of Multivendor 
Hota, J.

Nasim, S.

Mishra, S.
Hota, J., \& Mishra, S.(2018) "Development and Validation of a Multivendor ATM Adoption Model in India", International Journal of Bank Marketing, Forthcoming.

Chau, P.Y. (2001) "Influence of computer attitude and self-efficacy on IT usage behavior", Journal of Organizational and End User Computing, 13(1): 26. https://dx.doi.org//10.4018/ joeuc. 2001010103.

Reid, M., \& Levy, Y. (2008) "Integrating trust and computer self-efficacy with TAM: An empirical assessment of customers' acceptance of banking information systems (BIS) in Jamaica", Journal of Internet Banking and Commerce, 12(3):1-17.

Sathye, S., \& Sathye, M. (2017) "Do ATMs Increase Technical Efficiency of Banks in a Developing Country? Evidence from Indian Banks", Australian Accounting Review, 27(1), 101-111. https://dx.doi.org/10.1111/auar.12110.

Sushil. (2005a) "Interpretive Matrix: A Tool to Aid Interpretation of Management in Social Research", Global Journal of Flexible System Management, 6(2), 27-30.

Sushil. (2005b) "A flexible strategy framework for managing continuity and change", International Journal of Global Business and Competitiveness, 1(1). 22-32. https://dx.doi. org//10.1109/PICMET.2009.5261765.

Sushil (2012) "Interpreting the Interpretive Structural Model", Global Journal of Flexible Systems Management, 13(2), 87-106. https://dx.doi.org//10.1007/s40171-012-0008-3.

Swaminathan, B.(2017) “ATM Maker Diebold Sees Demonetization As Big Business Opportunity available at http://www.cxotoday.com/story/atm-maker-diebold-banks-onindia-market-demonetization-for-growth/ fetched on 12.01.2018.

Luken, R., \& Van Rompaey, F. (2008) "Drivers for and barriers to environmentally sound technology adoption by manufacturing plants in nine developing countries", Journal of Cleaner Production, 16(1), S67-S77. https://dx.doi.org/10.1016/j.jclepro.2007.10.006.

McCreadie, M., Rice, R. (1999) "Trends in Analysing Access to Information", Information Processing and Management 35 (1), 45-76, 77-99. https://dx.doi.org/10.1016/S03064573(98)00037-5

Dwivedi, Y. K., Lal, B., \& Williams, M. D. (2009) "Managing Consumer Adoption of Broadband: Examining Drivers and Barriers", Industrial Management \& Data Systems, 109(3), 357369. https://dx.doi.org/10.1108/02635570910939380

Del Río González, P. (2005) “Analysing the Factors Influencing Clean Technology Adoption: A Study of the Spanish Pulp and Paper Industry", Business Strategy and The Environment, 14(1), 20-37. https://dx.doi.org/10.1002/bse.426.

Ani.(2017) "Diebold Nixdorf completes 25 yrs in India; to expand footprint in retail available at http://www.business-standard.com/article/news-ani/diebold-nixdorf-completes-25-yrs-inindia-to-expand-footprint-in-retail-117070700954_1.html fetched on 1.1.2018.

Hota, J.,\& Nasim,S.(October,2015) "Drivers and Barriers in Adopting Multivendor ATM Technology for Banks in India Available at https://papers.ssrn.com/sol3/papers. cfm?abstract_id $=2712659$

Davis,F. D.(1989) "Perceived usefulness, perceived ease of use, and user acceptance of information technology. MIS quarterly, 319-340.

Davis, F. D., Bagozzi, R. P., \& Warshaw, P. R. (1989) “User Acceptance of Computer Technology: A Comparison of Two Theoretical Models", Management Science, 35(8), 982-1003.

Hota, J.(2017) :Adoption of Multivendor ATM Technology in India(Unpublished doctoral dissertation), Aligarh Muslim University, Aligarh, India.

Kumar, L., Malathy, D. and Ganesh, L.S.(2011) "The Diffusion of ATM Technology in Indian Banking, Journal of Economic Studies, 38(4): 483-500. https://dx.doi. org/10.1108/01443581111160905.

Journal of Technology Management for Growing Economies, Volume 9, Number 1, April 2018 
De Angeli, A., Athavankar, U., Joshi, A., Coventry, L., \& Johnson, G. I. (2004) "Introducing ATMs in India: A Contextual Inquiry", Interacting with Computers, 16(1), 29-44. https:// dx.doi.org/10.1016/j.intcom.2003.11.003.

Moutinho, L., \& Meidan, A.(1989) "Bank Customer's Perceptions, Innovations and New Technology", International Journal of Bank Marketing, 7(2),22-27. https://dx.doi. org/10.1108/EUM0000000001455.

Venkatesh, V., \& Davis, F. D. (2000) 'A theoretical extension of the technology acceptance model: Four longitudinal field studies", Management Science, 46(2), 186-204. https:// dx.doi.org/10.1287/mnsc.46.2.186.11926.

Drivers and

Barriers to Adoption of Multivendor

Mishra, S., \& Suar, D.(2007) "Do Lessons People Learn Determine Disaster Cognition and Preparedness?", Psychology and Developing Societies,19(2),143-159. 